\title{
Studies on the Site Specific Nutrient Management Practices for Balanced Fertilization in Cassava (Manihot esculenta Crantz)
}

\author{
M. Velmurugan*, L. Pugalendhi, S. Manickam, S. Suganya, \\ P. R. Kamalkumaran and M. Anand
}

Tamil Nadu Agricultural University, Tapioca and Castor Research Station, Yethapur, India

*Corresponding author

\begin{abstract}
A B S T R A C T
Cassava is an important tuber crop cultivated in Tamil Nadu. Being a long duration crop, judicious application of nutrients is important for getting higher tuber yield. In Tamil Nadu, invariably of the soil nutrient status, the blanket fertilizer recommendation is 90: 90: $240 \mathrm{~kg}$ of NPK/ha. A field experiment was conducted at Tapioca and Castor Research Station, Yethapur under AICRP Tuber crops Programme to study the site specific nutrient recommendations for cassava in red non calcareous soil (Typic Rhodustalf, Irrugur series) on the growth, tuber yield and starch content of cassava. The cassava variety Sree Vijaya was planted in ridges and furrows at a spacing of $90 \times 75 \mathrm{~cm}$. Based on the initial availability of nutrients, the experiment was planned with six treatments in Randomized Block Design (RBD) with four replications. The varying doses of fertilizers was compared with the farmers practice $(90: 70: 280 \mathrm{~kg} / \mathrm{ha})$. The final soil sample was collected during the time of harvest of the crop. The results of the experiment revealed that the tallest plants $(54.22,106.97,142.96$ and $187.65 \mathrm{~cm})$ and maximum number of leaves $(40.00,110.00$, 132.00 and 119.66) was recorded in $2^{\text {nd }}, 4^{\text {th }}, 6^{\text {th }}$ and $8^{\text {th }}$ months after planting in site specific based nutrient application (115:50:35 kg NPK/ha) respectively. The differential application of nutrients influenced the tuber yield. The mean tuber yield of $36.89 \mathrm{t} \mathrm{ha}^{-1}$ was recorded by the application of 115:50:35 kg NPK/ha. However, the farmers practice (90:70:280 kg/ha) recorded the lowest weight of stem $(0.72 \mathrm{~kg})$, weight of tuber $(1.35 \mathrm{~kg}$ plant $\left.^{-1}\right)$ and mean tuber yield $\left(13.94 \mathrm{tha}^{-1}\right)$. Based on the experimental results, precise and balanced application of fertilizers can be achieved with maximum tuber yield and starch content.
\end{abstract}

\section{Introduction}

Cassava or tapioca (Manihot esculenta Crantz.) is an important tuber crop belongs to the family Euphorbiaceae. This crop is well known for its tolerance to drought, adaptability to poor soil condition, pest and diseases. This crop is cultivated both in irrigated and rainfed conditions. In India, it is cultivated mainly in Kerala, Tamil Nadu, Karnataka and Andhra Pradesh. Kerala and Tamil Nadu account for about $80 \%$ of the total acreage of the crop in India. During 2018-19, cassava is cultivated in an area of 1.73 lakh hectares with the production of 49.50 lakh tonnes (NHB, 2019). Cassava is 
mainly cultivated in Salem, Namakkal, Cuddalore, Villupuram, Dharmapuri and Kanyakumari districts of Tamil Nadu. The major area under cassava cultivation is confined to Dharmapuri district (25\%) followed by Namakkal district (18\%) and Salem district (16\%).

In Tamil Nadu, Cassava is mainly grown in rainfed conditions as mono-crop year after year in the same field without any crop rotation. Being a tuberous crop, the tuber yield mainly depends on the nutritional status of soil and judicious application of fertilizers. Site-specific nutrient management (SSNM) and planning for nutrient inputs is needed for optimizing economic return and minimizing effects on environmental quality (Agustin Pagani et al., 2013). SSNM strives to enable the farmers to dynamically adjust fertilizer use to optimally fill the deficit between the nutrient needs of a high yielding crop and the nutrient supply from naturally occurring indigenous sources, including soil, crop residues, manures, and irrigation water (Buresh and Witt (2006) and Janssen (1990). Considering the wastage and enormous application of fertilizers, it necessary to study the location specific requirement of fertilizers for cassava through initial soil analysis. Based on the nutrient availability, Site-specific nutrient management (SSNM) experiment was conducted to study the influence of soil test based fertilizer application in red non calcareous soil (Typic Rhodustalf, Irrugur series) on the growth, tuber yield and starch content of cassava.

\section{Materials and Methods}

The field experiment was conducted at Tapioca and Castor Research Station, Yethapur, Salem ( $11^{\circ} 35^{\prime} \mathrm{N}$ latitude, $78^{\circ} 29^{\prime}$ E longitude) under AICRP Tuber crops Programme. Experimental site was located in North Western Zone of Tamil Nadu. Initial soil sample analysis revealed that $\mathrm{pH}(7.41)$, EC $\left(0.26 \mathrm{dsm}^{-1}\right)$, Organic carbon $(0.30 \%)$, available Nitrogen $(193.64 \mathrm{~kg} / \mathrm{ha})$, available Phosphorus $(6.11 \mathrm{~kg} / \mathrm{ha})$ and available Potash $(329.14 \mathrm{~kg} / \mathrm{ha})$ which indicated the low medium level of nitrogen and phosphorous and higher availability of potash. Based on the nutrient availability and the yield targets of cassava, six treatments was designed in RBD with four replications viz., $\mathrm{T}_{1}$ 100:50:100 $\mathrm{kg} \quad \mathrm{NPK} / \mathrm{ha} \quad$ (blanket recommendation of fertilizer), $\mathrm{T}_{2}-115: 50: 35$ $\mathrm{kg} \quad \mathrm{NPK} / \mathrm{ha}$ (fertilizer recommendation specific to the location), $\mathrm{T}_{3}-0: 75: 50 \mathrm{~kg}$ NPK/ha (zero nitrogen), $\mathrm{T}_{4}-140: 0: 50 \mathrm{~kg}$ NPK/ha (zero phosphorous), $\mathrm{T}_{5}-140: 75: 0 \mathrm{~kg}$ NPK/ha (zero potash) and $\mathrm{T}_{6}-$ Control (FYM@ 12 t/ha). The cassava sets of variety Sree Vijaya were planted in ridges and furrows method at a spacing of $90 \times 75 \mathrm{~cm}$. Observation on growth parameter viz., plant height and number of leaves, physiological parameters viz., leaf area index number of fallen leaves at harvest, number of standing leaves at harvest, weight of standing leaves at harvest $(\mathrm{kg})$, weight of stem $(\mathrm{kg})$, weight of tuber $\left(\mathrm{kg} \mathrm{plant}^{-1}\right)$, tuber yield $\left(\mathrm{ha}^{-1}\right)$ and starch content $(\%)$ were recorded.

Standard cultivation practices recommended for cassava as per crop production techniques of Horticultural crops (2013) published by TNAU were adopted uniformly for all experimental plots. The data on various parameters studied during the course of investigation were statistically analyzed and applying the technique of analysis of variance suggested by Panse and Sukhatme (1985).

\section{Results and Discussion}

\section{Growth parameters}

The experimental data on the growth parameters revealed that during $2^{\text {nd }}, 4^{\text {th }}, 6^{\text {th }}$ and $8^{\text {th }}$ months after planting, the tallest plants 
(54.22, 106.97, 142.96 and $187.65 \mathrm{~cm})$ and the shortest plants $(27.69,84.79,110.22$ and $138.96 \mathrm{~cm})$ were recorded in $\mathrm{T}_{2}(115: 50: 35$ kg NPK/ha) and T6 (Control - FYM@ 12 t/ha) respectively.

Table.1 Site specific nutrient management practices on plant height $(\mathrm{cm})$ of cassava

\begin{tabular}{|c|c|c|c|c|c|}
\hline \multirow{2}{*}{\multicolumn{2}{|c|}{ Treatments }} & \multicolumn{4}{|c|}{ Plant height (cm) } \\
\hline & & 2 MAP & 4 MAP & 6 MAP & 8 MAP \\
\hline T1 & 100:50:100 kg NPK/ha & 42.34 & 90.60 & 136.80 & 163.13 \\
\hline T2 & $115: 50: 35 \mathrm{~kg} \mathrm{NPK} / \mathrm{ha}$ & 54.22 & 106.97 & 142.96 & 187.65 \\
\hline T3 & 0:75:50 kg NPK/ha & 31.15 & 70.00 & 119.39 & 148.91 \\
\hline T4 & 140:0:50 kg NPK/ha & 40.49 & 95.93 & 130.13 & 169.52 \\
\hline T5 & 140:75:0 kg NPK/ha & 36.21 & 94.75 & 118.72 & 156.26 \\
\hline T6 & Control (FYM@ 12t/ha) & 27.69 & 84.79 & 110.22 & 138.96 \\
\hline & $\mathrm{CD}(0.05)$ & 9.45 & 25.13 & 35.66 & 22.05 \\
\hline & SEd & 4.73 & 12.54 & 17.83 & 11.02 \\
\hline
\end{tabular}

MAP - Months after planting

Table.2 Site specific nutrient management practices on number of leaves of cassava

\begin{tabular}{|c|l|c|c|c|c|}
\hline \multicolumn{2}{|c|}{ Treatments } & \multicolumn{4}{c|}{ Number of leaves } \\
\cline { 2 - 6 } & & 2 MAP & 4 MAP & 6 MAP & 8 MAP \\
\hline T1 & 100:50:100 kg NPK/ha & 32.33 & 96.33 & 119.33 & 110.33 \\
\hline T2 & $115: 50: 35 \mathrm{~kg} \mathrm{NPK} / \mathrm{ha}$ & 40.00 & 110.00 & 132.00 & 119.66 \\
\hline T3 & $0: 75: 50 \mathrm{~kg} \mathrm{NPK} / \mathrm{ha}$ & 25.66 & 73.00 & 91.66 & 78.00 \\
\hline T4 & $140: 0: 50 \mathrm{~kg} \mathrm{NPK} / \mathrm{ha}$ & 37.00 & 85.33 & 121.00 & 105.00 \\
\hline T5 & $140: 75: 0 \mathrm{~kg} \mathrm{NPK} / \mathrm{ha}$ & 32.33 & 92.00 & 129.66 & 98.33 \\
\hline T6 & Control (FYM@ 12t/ha) & 21.66 & 66.33 & 98.33 & 81.33 \\
\hline & CD(0.05) & 5.77 & 13.35 & 19.53 & 8.16 \\
\hline & SEd & 2.86 & 6.55 & 9.66 & 4.07 \\
\hline
\end{tabular}

MAP - Months after planting

Table.3 Site specific nutrient management practices on leaf area index of cassava

\begin{tabular}{|c|l|c|c|c|c|}
\hline \multicolumn{2}{|c|}{ Treatments } & \multicolumn{4}{c|}{ Leaf area index } \\
\cline { 2 - 6 } & & 2 MAP & 4 MAP & 6 MAP & 8 MAP \\
\hline T1 & 100:50:100 kg NPK/ha & 62.10 & 92.40 & 116.70 & 102.10 \\
\hline T2 & $115: 50: 35 \mathrm{~kg} \mathrm{NPK} / \mathrm{ha}$ & 89.20 & 115.60 & 141.00 & 124.20 \\
\hline T3 & 0:75:50 kg NPK/ha & 31.90 & 56.00 & 77.30 & 64.80 \\
\hline T4 & $140: 0: 50 \mathrm{~kg} \mathrm{NPK} / \mathrm{ha}$ & 49.40 & 68.10 & 92.00 & 75.20 \\
\hline T5 & 140:75:0 kg NPK/ha & 55.70 & 74.90 & 102.10 & 88.30 \\
\hline T6 & Control (FYM@ 12t/ha) & 41.20 & 59.00 & 88.90 & 63.00 \\
\hline & CD(0.05) & 16.97 & 27.12 & 29.65 & 28.75 \\
\hline & SEd & 8.48 & 13.61 & 14.83 & 14.35 \\
\hline
\end{tabular}

MAP - Months after planting 
Table.4 Site specific nutrient management practices on number of fallen leaves at harvest, number of standing leaves at harvest and weight of standing leaves at harvest $(\mathrm{kg})$

\begin{tabular}{|r|l|c|c|c|}
\hline \multicolumn{2}{|c|}{ Treatments } & $\begin{array}{c}\text { Number of } \\
\text { fallen leaves } \\
\text { at harvest }\end{array}$ & $\begin{array}{c}\text { Number of } \\
\text { standing leaves } \\
\text { at harvest }\end{array}$ & $\begin{array}{c}\text { Weight of } \\
\text { standing leaves at } \\
\text { harvest (kg) }\end{array}$ \\
\hline T1 & 100:50:100 kg NPK/ha & 65.33 & 47.00 & 0.38 \\
\hline T2 & $115: 50: 35 \mathrm{~kg} \mathrm{NPK} / \mathrm{ha}$ & 78.00 & 55.33 & 0.49 \\
\hline T3 & $0: 75: 50 \mathrm{~kg} \mathrm{NPK/ha}$ & 57.66 & 42.66 & 0.30 \\
\hline T4 & $140: 0: 50 \mathrm{~kg} \mathrm{NPK/ha}$ & 65.33 & 49.33 & 0.42 \\
\hline T5 & $140: 75: 0 \mathrm{~kg} \mathrm{NPK/ha}$ & 71.00 & 40.00 & 0.46 \\
\hline T6 & Control (FYM@ 12t/ha) & 44.66 & 39.33 & 0.22 \\
\hline & $\mathbf{C D ( 0 . 0 5 )}$ & 14.33 & 8.77 & 0.091 \\
\hline & SEd & 7.15 & 4.38 & 0.045 \\
\hline
\end{tabular}

Table.5 Site specific nutrient management practices on weight of stem $(\mathrm{kg})$ and weight of tuber $\left(\mathrm{kg} \mathrm{plant}^{-1}\right)$

\begin{tabular}{|c|c|c|c|c|c|}
\hline \multicolumn{2}{|r|}{ Treatments } & \multirow{2}{*}{$\begin{array}{c}\begin{array}{c}\text { Weight of } \\
\text { stem }(\mathbf{k g})\end{array} \\
1.23\end{array}$} & \multirow{2}{*}{$\begin{array}{c}\begin{array}{c}\text { Weight of tuber } \\
\text { (kg plant } \\
\text { (kg })\end{array} \\
2.95\end{array}$} & \multirow{2}{*}{$\begin{array}{c}\begin{array}{c}\text { Tuber } \\
\text { yield }\left(\mathbf{h a}^{-1}\right)\end{array} \\
29.31\end{array}$} & \multirow{2}{*}{$\begin{array}{c}\begin{array}{c}\text { Starch } \\
\text { content (\%) }\end{array} \\
23.80\end{array}$} \\
\hline T1 & 100:50:100 kg NPK/ha & & & & \\
\hline T2 & 115:50:35 kg NPK/ha & 1.47 & 3.80 & 35.16 & 24.30 \\
\hline T3 & 0:75:50 kg NPK/ha & 0.95 & 2.31 & 29.05 & 23.00 \\
\hline T4 & 140:0:50 kg NPK/ha & 1.19 & 2.10 & 25.10 & 23.50 \\
\hline T5 & 140:75:0 kg NPK/ha & 1.27 & 1.99 & 19.80 & 22.10 \\
\hline \multirow[t]{3}{*}{ T6 } & Control (FYM@ 12t/ha) & 0.72 & 1.35 & 15.96 & 21.90 \\
\hline & $\mathrm{CD}(0.05)$ & 0.78 & 0.67 & 5.09 & 5.33 \\
\hline & SEd & 0.39 & 0.33 & 2.45 & 2.65 \\
\hline
\end{tabular}

Table.6 Site specific nutrient management practices on mean tuber yield $\left(\mathrm{t} \mathrm{ha}^{-1}\right)$ and starch content in tubers $(\%)$

\begin{tabular}{|c|c|c|c|}
\hline \multicolumn{2}{|r|}{ Treatments } & Mean tuber yield & Mean starch content in \\
\hline T1 & 100:50:100 kg NPK/ha & 31.75 & 23.77 \\
\hline T2 & 115:50:35 kg NPK/ha & 36.89 & 24.73 \\
\hline T3 & 0:75:50 kg NPK/ha & 28.12 & 23.17 \\
\hline T4 & 140:0:50 kg NPK/ha & 23.96 & 22.67 \\
\hline T5 & 140:75:0 kg NPK/ha & 19.05 & 22.57 \\
\hline T6 & Control(FYM@12t/ha) & 13.94 & 22.50 \\
\hline \multicolumn{2}{|r|}{$\mathrm{CD}(0.05)$} & 5.96 & 6.56 \\
\hline \multicolumn{2}{|r|}{ SEd } & 2.98 & 3.28 \\
\hline
\end{tabular}


The maximum number of leaves (40.00, $110.00,132.00$ and 119.66) was recorded in $2^{\text {nd }}, 4^{\text {th }}, 6^{\text {th }}$ and $8^{\text {th }}$ months after planting in 115:50:35 kg NPK/ha $\left(T_{2}\right)$, whereas minimum number of leaves $(21.66,66.33,98.33$ and 81.33) was recorded in $\mathrm{T}_{6}$ (Control - FYM@ $12 \mathrm{t} / \mathrm{ha}$ ) (Table 1 and 2).

\section{Physiological parameters}

The maximum leaf area $(89.20,115.60$, 141.00 and 124.20) was recorded in 115:50:35 kg NPK/ha $\left(\mathrm{T}_{2}\right)$ when compared to other treatments. The pooled mean data revealed that there was no significant difference among the treatments on the number of fallen leaves at the time of harvest, number of standing leaves at harvest, weight of standing leaves at harvest $(\mathrm{kg})$ and weight of the stem $(\mathrm{kg})$ (Table 3 and 4).

\section{Yield parameters}

The differential application of fertilizers significantly influenced the tuber yield and number of tubers in cassava. The differential application of nutrients influenced the tuber yield of cassava. The highest $\left(3.80 \mathrm{~kg} \mathrm{plant}^{-1}\right)$ and the lowest $\left(1.35 \mathrm{~kg} \mathrm{plant}^{-1}\right)$ weight of tuber was recorded in 115:50:35 kg NPK/ha $\left(\mathrm{T}_{2}\right)$ and $\mathrm{T}_{6}$ (Control - FYM@ 12 t/ha) respectively. The mean tuber yield $(36.89 \mathrm{t}$ $\mathrm{ha}^{-1}$ ) was recorded by the application of 115:50:35 $\mathrm{kg} \mathrm{NPK} / \mathrm{ha}\left(\mathrm{T}_{2}\right)$. However, the control (FYM@12 t/ha) recorded the lowest mean tuber yield (13.94 t/ha) (Table 5 and 6). Site specific nutrient management (SSNM) is the application of plant nutrients based on the soil and crop need and utilization of optimal fertilizer rates to achieve higher nutrient use efficiency (Byju et al., 2016).

Nitrogen is typically taken up in larger amounts than other nutrients which facilitate the vegetative growth of the plants. One of the reasons attributed to the lower tuber yield in cassava might be due to the imbalanced application of fertilizers that might not have supported the growth and tuber development of cassava. Similarly, Phosphorus (P) is an essential nutrient for crop production since it is required for many plant functions, including energy transfer and protein synthesis. The plants require $\mathrm{K}$ for photosynthesis, synthesis of ATP (an energy exchange compound), many carbohydrates and proteins; translocation of sugars. Adequate K supply strengthens plant stem, thus helping reduce lodging and also increases resistance to several diseases through a variety of mechanisms. These results are in agreement with the findings of Phonde and Zende (2007), Nerkar and Phonde (2009), Oad et al., 2009 and Prince Kumar et al., (2016).

The Site-specific nutrient management (SSNM) in cassava variety Sree vijaya at Yethapur condition revealed that the tallest plants, maximum number of leaves was recorded in all the stages of growth and mean tuber yield in site specific based nutrient application (115:50:35 kg NPK/ha). However, the farmers practice $(90: 70: 280 \mathrm{~kg} / \mathrm{ha})$ recorded the lowest weight of stem, weight of tuber and mean tuber yield. Based on the experimental results, precise and balanced application of fertilizers can be achieved with maximum tuber yield and starch content.

\section{References}

Agustin Pagani, John E. Sawyer and Antonio P. Mallarino. 2013. Site-Specific Nutrient Management for nutrient management planning to improve crop production, environmental quality, and economic return. Natural resources conservation service. Pp.1- 15.

Buresh R.J., and C. Witt. 2006. The principles of Site-Specific Nutrient Management. Research Findings: e-ifc No. 10. 
Byju, G., M, Nedunchezhiyan, James George, S. Sunitha, P. R. Kamalkumaran, P.P. Singh, K.Mamatha, Surajit Mitra, Jayanta Tarafdar, Ketan Desai, V. Ravi, M. Vani, Sabitha Soman and K.R. Remya Remesh. 2016. Fertilizer best management practices by SSNM and customized fertilizers for elephant foot yam (Amorphophallus paeoniifolius) cultivation in India. Indian $J$. Agricultural Sci. 86 (4): 485-93.

Crop production techniques of horticultural crops. 2013. Horticultural College and Research Institute, Tamil Nadu Agricultural University, Coimbatore $641003.137-140$.

Janssen, B.H., Guiking, F.C.T., van der Eijk, D., Smaling, E.M.A., Wolf, J. and H. van Reuler. 1990. A system for quantitative evaluation of the fertility of tropical soils (QUEFTS). Geoderma 46: 299-318.

National Horticultural Board, 2019. Area and Production of Horticulture Crops - All India. Pp.1-3.

Nerkar, Y. S. and D. B.Phonde.2009. Sitespecific nutrient management for maximum economic yield and quality of sugarcane in Maharashtra. www.ipni.net.

Oad, F. C., U. A. Buriro, M. U. Usmanikhail and M. K. Siddiqui.2009. Qualitative and quantitative parameters of sugarcane crop under different sources of fertilizers. Pak. Sugar J., 24(1): 1014.

Panse, V. G., and Sukhatme, P. V. 1985. Statistical methods for agricultural workers. ICAR, New Delhi. Pp.134192.

Phonde, D. B. and N. A. Zende.2007. Site specific nutrient management for maximum yield and quality of sugarcane. Paper presented In: Nation. Seminar on Integrated Nutrient Management in Sugarcane Cultivation, Vasantdada Sugar Institute, Pune, 27-28 February, 2007.

Prince Kumar, G. Byju, B. P. Singh, J. S. Minhas and V. K. Dua. 2016. Application of QUEFTS Model for Site-Specific Nutrient Management of NPK in Sweet Potato (Ipomoea batatas L. Lam). Comm. Soil Sci. and Plant Analysis, 47 (13-14): 1599-1611.

\section{How to cite this article:}

Velmurugan, M., L. Pugalendhi, S. Manickam, S. Suganya, P. R. Kamalkumaran and Anand, M. 2020. Studies on the Site Specific Nutrient Management Practices for Balanced Fertilization in Cassava (Manihot esculenta Crantz). Int.J.Curr.Microbiol.App.Sci. 9(08): 3111-3116. doi: https://doi.org/10.20546/ijcmas.2020.908.353 